\title{
CHARACTERIZATION OF TRACE GASES AND GREEN HOUSE GAS IN MEGACITY NEW DELHI
}

\author{
Arti Choudhary ${ }^{*}$, Pradeep Kumar ${ }^{2}$, Anuradha Shukla ${ }^{1}$, Siddhartha Singh $^{3}$, Abhay Kumar Singh ${ }^{2}$ \\ ${ }^{1}$ Tansport Planning and Environment Division, CSIR-Central Road Research Institute, New Delhi, India \\ ${ }^{2}$ Department of Physics, Institute of Science, Banaras Hindu University, Varanasi, India \\ ${ }^{3}$ India Meteorological Department, New Delhi, India \\ *Email: choudharyarti12@gmail.com
}

\begin{abstract}
Air pollution and climate change is serious environmental concern due to its visible negative impact on human health. Around 14 Indian cities are placed among top 20 most polluted cities of the world. Trace gas like $\mathrm{O}_{3}, \mathrm{NO}_{\mathrm{x}}, \mathrm{CO}$ and $\mathrm{CO}_{2}$ are important pollutants which is associated with human health, climate change and adverse effect on growth and yield of crops. Stratospheric $\mathrm{O}_{3}$ absorbs ultraviolet light and prevents it from reaching to the ground. Greenhouse effect of $\mathrm{O}_{3}$ and $\mathrm{CO}_{2}$ is prominent, $\mathrm{O}_{3}$ in upper troposphere and ranked $3^{\text {rd }}$ for its radiative potential after the carbon dioxide and methane. The amount of $\mathrm{O}_{3}$ generated by photochemical reaction of air pollutants is much larger than the inflow from the stratosphere. This is indicating that trace gases and GHG are generated by anthropogenic activities. It is significantly high in urban area like megacity Delhi as compared to rural area due to excessive anthropogenic activity.

The ground level measurements of surface trace gas like $\mathrm{O}_{3}, \mathrm{NO}_{\mathrm{x}}, \mathrm{CO}$ and $\mathrm{CO}_{2}$ were conducted in Delhi-Mathura road near traffic intersection for year 2017, January to December. The daily mean concentration of $\mathrm{O}_{3}, \mathrm{NO}_{x}, \mathrm{CO}$ and $\mathrm{CO}_{2}$ were $23.11 \pm 17.26 \mathrm{ppb}$ (range 58.38 to $6.42 \mathrm{ppb}$ ), $26.41 \pm 4.24 \mathrm{ppb}$ (ranges 48.14 to $24.09 \mathrm{ppb}$ ), $1.56 \pm 4.24 \mathrm{ppm}$ (ranges 6.6 to $0.69 \mathrm{ppm}$ ) and $342.54 \pm 33.49$ (ranges 508.23 to $323.33 \mathrm{ppm}$ ), respectively. The mixing ratios of $\mathrm{O}_{3}$ were highest of $32 \mathrm{ppbv}$ and lowest $17 \mathrm{ppbv}$ during the premonsoon and monsoon seasons, respectively. While the mixing ratios of both $\mathrm{CO}$ and $\mathrm{NO}_{\mathrm{x}}$ showed highest and lowest values during the winter and monsoon seasons, respectively.

The analysis concluded seasonality of $\mathrm{O}_{3}$, $\mathrm{CO}$ and $\mathrm{NO}_{\mathrm{x}}$ were also governed by the long-range transport, mainly with the summer and winter monsoon circulations over the Indian subcontinent. The mixing ratios of $\mathrm{CO}$ and $\mathrm{NO}_{\mathrm{x}}$ show strong correlations during winter and pre-monsoon seasons, while poor correlation in the monsoon
\end{abstract}

season. The mixing ratios of $\mathrm{CO}$ and $\mathrm{NO}_{\mathrm{x}}$ decreased with the increase in wind speed, while $\mathrm{O}_{3}$ tended to increase with the wind speed.

Keywords: Trace gases, GHG, seasonal variability, mixing rate, vehicular pollution

\section{METHODOLOGY}

Major vehicles for transportation are buses, cars, two- and three-wheelers (motorbikes, scooter and auto-rickshaws). Due to rapidly increasing number of vehicles (about $10-15 \%$ per year), the transport related activities are the major contributors of various pollutants [1-3]. The real time automatic data of ambient pollutant concentration and meteorological data were collected from Automatic Weather Station (AWS) and Automatic Rain Gauge (ARG) for the Year 2017, installed by India Meteorological Department (IMD, India) at Delhi-Mathura Road/National Highway 2 (NH2) passing through Delhi to Agra city. The site is geographically located at $28^{\circ} 37^{\prime} 39.99 \mathrm{~N}$ $77^{\circ} 14^{\prime} 29.04 \mathrm{E}$ at 216 meters above mean sea level (MSL). The ground measured concentration of trace gases $\mathrm{O}_{3} \mathrm{CO}, \mathrm{NO}_{\mathrm{x}}$ and $\mathrm{CO}_{2}$ will be considered for the analysis. The site has very high inflow and outflow of vehicles, about 170,000 vehicles per day but there are other major sources of pollution located in the vicinity of the site, such as sewage treatment plant, gasoline stations and automobile workshops. The major sources of gaseous pollutants in the surrounding areas of the site are vehicular exhaust and biofuel burning. The vehicle composition consists of mainly two-wheelers, three-wheelers, cars, buses and light commercial vehicles (LCVs) during day time and heavy-duty trucks during the night hours [4-6].

\section{RESULTS}

\subsection{Diurnal variation of trace gases}

The basic dataset in the present study were recorded for $30 \mathrm{~min}$ interval and averaging has 
been done to derive hourly data. The amplitude of diurnal distribution varied from month to month. The diurnal distributions of $\mathrm{O}_{3}$ in the pre-monsoon, post-monsoon and winters seasons show strong variability (Figure 1). However, the distribution of $\mathrm{O}_{3}$ in the monsoon season shows weaker diurnal dependency. The maximum $\mathrm{O}_{3}$ and minimum $\mathrm{NO}_{x}$ concentration were found during 14-17 hour and min $\mathrm{CO}, \mathrm{CO}_{2}$ concentration during 13-16 hr and maximum concentration were found during morning and evening traffic peak hour (7-11am and 17-20pm, Figure 1).
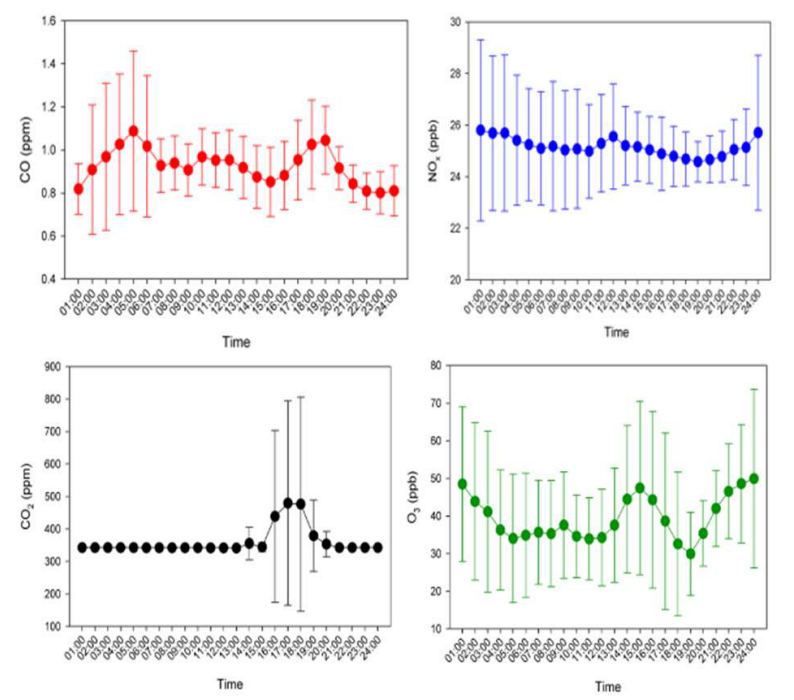

Figure 1: Diurnal variation of air pollutants.

The degree of diurnal variability in both $\mathrm{CO}$ and $\mathrm{NO}_{\mathrm{x}}$ varied from month to month with strong variability in the pre monsoon, post-monsoon and winters seasons, while weaker diurnal dependency in the monsoon season. The mixing ratios of both $\mathrm{CO}$ and $\mathrm{NO}_{\mathrm{x}}$ show a sharp peak in the morning hours between $07 \mathrm{hr}$ and $10 \mathrm{hr}$. Due to elevated planetary boundary layer mixing ratios were observed in the afternoon hours (13-16 hr). The observations from night till early morning hours show high values mainly due to shallow nocturnal boundary layer depth, resisting the mixing of local emissions with the free tropospheric air. In other hand, during after noontime the higher PBL depth provides a larger mixing region and hence the pollutants get diluted. The morning and evening peaks are almost absent during monsoon months and lower concentrations of both $\mathrm{NO}_{\mathrm{x}}$ and $\mathrm{CO}$ were observed with no significant differences between day and night.

\subsection{Seasonal variation of trace gases and GHG gas}

The higher $\mathrm{O}_{3}$ concentrationwas found in the premonsoon and winter seasons and it associated with the elevated levels of $\mathrm{NO}_{\mathrm{x}}$. The lower concentration of $\mathrm{O}_{3}$ in the monsoon and postmonsoon seasons were associated with the lower concentration of $\mathrm{NO}_{\mathrm{x}}$. It is also evident that the highest $\mathrm{O}_{3}$ mixing ratio was observed in the pre-monsoon season, while the maxima in precursor species were observed in the winter seasons (Figure 2).

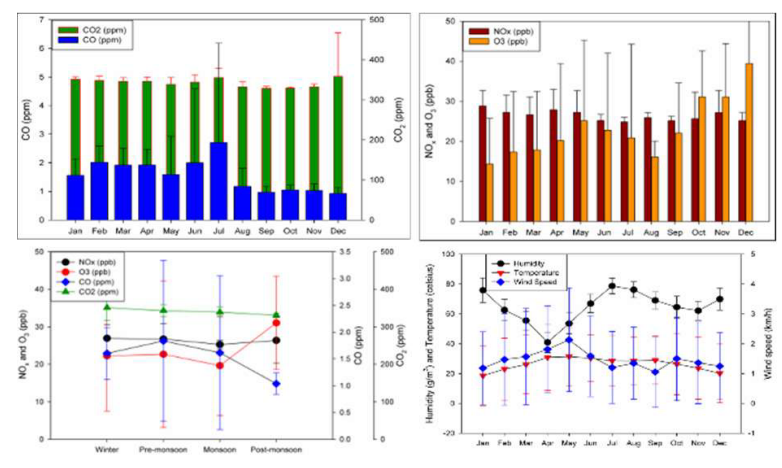

Figure 2: Monthly variation (top), seasonal variation (bottom) of pollutants.

However, $\mathrm{CO}$ and $\mathrm{CO}_{2}$ concentration were found more or less similar trend throughout the year. It is indicating similar source and dominant through-out the year like roadway transportation. The seasonal changes in the long-range transport, emission, boundary layer height and photochemistry (via $\mathrm{OH}$ oxidation) play important roles in the observed seasonal variation of $\mathrm{O}_{3}$ and $\mathrm{NO}_{\mathrm{x}}$ concentration.

However, to stimulate the contributions of these processes require detailed model simulation dealing with these processes on local scale. During winter season, Indo-Gangetic Plain influenced the site leading to highest levels of $\mathrm{NO}_{\mathrm{x}}$.

\section{ACKNOWLEDGEMENTS}

Present study is financially supported by the SERB, New Delhi, India, under the scheme of SERB National Post-Doctoral Fellowship (PDF/2017/001284). Air Quality and Metrological 
data were taken from India Meteorological Department (IMD), New Delhi.

\section{REFERENCES}

[1] Choudhary, A., \& Gokhale, S. Urban real-world driving traffic emissions during interruption and congestion. Transportation Research Part D: Transport and Environment, 43: 59-70 (2016).

[2] Choudhary, A., \& Gokhale, S. On-road measurements and modelling of vehicular emissions during traffic interruption and congestion events in an urban traffic corridor. Atmospheric Pollution Research, 10: 480-492 (2019).

[3] Choudhary, A., \& Gokhale, S. Evaluation of emission reduction benefits of traffic flow management and technology upgrade in a congested urban traffic corridor. Clean Technologies and Environmental Policy, 21: 257-273 (2019).

[4] Choudhary, A., Kumar, P., Gaur, M., Prabhu, V., Shukla, A., \& Gokhale S. Real world driving dynamics characterization and identification of emission rate magnifying factors for auto-rickshaw. Nature Environment and Pollution Technology (In Press) 2019. [5] Choudhary, A., Gokhale, S., Shukla, A., Kumar, P., Singh, A. K. Variability in emission rate of AutoRickshaw based on real world driving profile: A case study in Guwahati city. 2019 URSI Asia-Pacific Radio Science Conference (AP-RASC). IEEE, (2019).

[6] Choudhary, A., Gaur, M., Shukla, A. Megacities of developing countries. Air Pollution: Sources, Impacts and Controls, Oxford publisher (CABI Press) pp. 150162 (2019). 